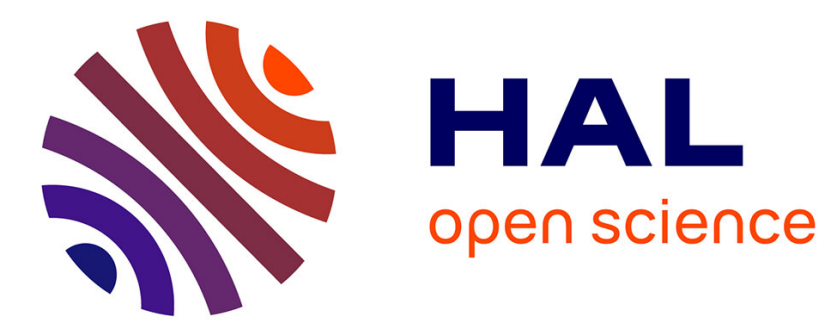

\title{
SURFACE TREATMENTS BY Cw YAG LASER
}

\author{
J. Jules, D. Grevey, Jean Pelletier, M. Pilloz, P. Kirat, A. Vannes
}

\section{To cite this version:}

J. Jules, D. Grevey, Jean Pelletier, M. Pilloz, P. Kirat, et al.. SURFACE TREATMENTS BY Cw YAG LASER. Journal de Physique IV Proceedings, 1991, 01 (C7), pp.C7-61-C7-64. 10.1051/jp4:1991713 . jpa-00250780

\section{HAL Id: jpa-00250780 https://hal.science/jpa-00250780}

Submitted on 1 Jan 1991

HAL is a multi-disciplinary open access archive for the deposit and dissemination of scientific research documents, whether they are published or not. The documents may come from teaching and research institutions in France or abroad, or from public or private research centers.
L'archive ouverte pluridisciplinaire HAL, est destinée au dépôt et à la diffusion de documents scientifiques de niveau recherche, publiés ou non, émanant des établissements d'enseignement et de recherche français ou étrangers, des laboratoires publics ou privés. 


\title{
SURFACE TREATMENTS BY CW YAG LASER
}

J.C. JULES, D.F. GREVEY, J.M. PELLETIER*, M. PILLOZ*, P. KIRAT* and A.B. VANNES**

I.U.T du Creusot, Laboratoire de Thermomécanique, 12 rue de la Fonderie, F-71200 Le Creusot, France "I.N.SA. Lyon, GEMPPM/CALFETMAT, 20 avenue A. Einstein, F-69621 Villeurbanne cedex, France

${ }^{* *}$ Ecole Centrale de Lyon, MMP, Avenue G. de Collonges, F-69631 Ecully, France

\begin{abstract}
The feasability of surface treatments by cw YAG laser has been established. Concerning solid phasis treatment, we explored superficial quenching of grey cast iron. It brings out that it's no necessar to precoat the sample before treatment, the natural absorptivity is suffisant.

Concerning liquid phasis transformation two examples are presented : surface alloying and cladding. For the first one, the power required for a given melted depth is 2 times lower than for a $\mathrm{CO}_{2}$ beam. Concerning the second example, it appears that the use of a step index fiber could ameliorate obtained results. Finally from a metalurgical point of view, obtained structures are the same than with $\mathrm{a} \mathrm{CO}_{2}$ beam.
\end{abstract}

\section{INTRODUCTION}

Because of required power level the only use of $\mathrm{CO}_{2}$ laser was considered in material's surface treatments. Now $\mathrm{Cw}$ high power YAG laser (upper than $1 \mathrm{~kW}$ ) are marketed and the possibility of beam carrying through an optical fiber allows us to use it for new industrial applications.

In this paper, we illustrate the surface treatments possibilities both in solid phasis and in liquid phasis owing to a $\mathrm{Cw}$ beam coming from a $600 \mu \mathrm{m}$ diameter's gradient index's optical fiber coupled with a 1200W's Nec cw YAG laser [1].

\section{EXPERIMENTAL RESULTS}

\section{II.1 Solid phasis treatment}

Here we present surface quenching of a lamellar grey cast iron. The material contains about $3 \%$ of carbon and has a pearlitic matrix.

In view to determine the treatment's parameters we use Fouquet's chart [2] and we modify the results because of the variation in absorptivity due to :

- the different surface coatings (paint, grapite spray, Salt baths) [3]

- the difference in wavelenght ( $\mathrm{CO}_{2} / \mathrm{YAG}$ ) [4]

The figure (1) shows obtained results for a treatment with a power of $600 \mathrm{~W}$, a focal spot of $2 \mathrm{~mm}$ and a scaning speed of $55 \mathrm{~cm} / \mathrm{min}$. The microstructure is similar than those observed after a $\mathrm{CO}_{2}$ treatment. We have an incomplete dissolution of Carbon due to the kinetics and the result is that we can see graphite lamellar and pearlitic zone in treated area. Hardness measurments confirm results with value of $200 \mathrm{H}_{v o, 1}$ in non transformed zone and about $800 \mathrm{H}_{\mathrm{vo}, 1}$ in the treated parts. 
It is important to note that this treatment has been made on a sample free of coating. Indeed it doesn't exist significant difference in the result of the treatment if the sample is coated or not. In the meantime one exception appears when the surface coating is white paint (Titanium oxide). In this case the reflectivity is maximal and the treatment no possible.

\section{2 Liquid phasis treatments - Surface alloying}

The substrate is an aluminum alloyed with $5 \%$ of Silicon and $3 \%$ of Copper and coated owing to the plasma technic with Nickel $(4 \% \mathrm{Al})$. The depth of the coating varies from 80 to $125 \mu \mathrm{m}$. These materials are choose in view to compare surface alloying to those obtained by S. BONNET - JOBEZ [5] with a $\mathrm{CO}_{2}$ laser. The figure (2) illustrate a typical obtained alloy. In this case, the treatment's parameters are a power of $760 \mathrm{~W}$, a laser spot of $1 \mathrm{~mm}$, a scanning speed of $1 \mathrm{~m} / \mathrm{min}$ and a gazeous cover with nitrogen.

The realized alloy is about $300 \mu \mathrm{m}$ thick, value obtained only with a power of $1600 \mathrm{~W}$ in the case of $\mathrm{CO}_{2}$ laser. These results are confirmed by an EPFL's study [4].

The structure is a very fine dendritic stucture with a high hardness $\left(650 \mathrm{H}_{\mathrm{vo}, 2}\right)$. An XRay diffraction 's analysis allows us to connect this hardness to the presence of intermetallic compounds like $\mathrm{Al}_{3} \mathrm{Ni}, \mathrm{Al}_{3} \mathrm{Ni}_{2}$ and $\mathrm{Al}_{2} \mathrm{Cu}$.

Finally, from this study it brings out that the decrease of the power and the increase of interaction time enables to ameliorate the quality of the alloy (homogeneity, disappearance of cracks and porosity).

\section{3 Liquid phasis treatment - cladding}

We realize stellite cladding $(63 \% \mathrm{Co}, 28 \% \mathrm{Cr}, \mathrm{W}, 1,25 \% \mathrm{C})$ on a 304 stainless steel $(18 \% \mathrm{Cr}, 8 \% \mathrm{Ni})$. Our choice was advised by the fact that these materials are largely studied both in classic technology [6] and in $\mathrm{CO}_{2}$ laser technology [7].

The figure (3) presents a cladding made owing to a power of $1100 \mathrm{~W}$, a laser spot of $1,1 \mathrm{~mm}$ and a scanning speed of $90 \mathrm{~cm} / \mathrm{min}$. An hardness of $350 \mathrm{H}_{\mathrm{vo}, 1}$ shows that the dilution's rate is important $(\approx 20 \%)$. In the case of a quasi null dilution's rate, PILLOZ [7] measured hardness of about $600 \mathrm{Hvo}_{\mathrm{v}, 1}$. So this parameter must be controlled in order to insure the wanted treatment.

When the scaning speed decreases, we have a key hole and an higher dilution. To insure a correct geometry for the cladding we must prefer a step index fiber which gives a "flat hat" spatial repartition of the energy[8] and limits the apparition of a key hole.

The obtained microstruscture at the interface melted area/non melted area becomes visible on figure(4). Dendrits are perpendicular to the solidification front and we can see a zone with a planar solidification front, due to the low conductibility of the steel.

It's the same metallurgy than with $\mathrm{CO}_{2}$ laser. An X Ray diffraction of the cladding, of the substrate and of the powder shows that we have always a c.f.c. structure, with a coating's crystalline parameter equal to the inox one $(=3,57 \mathrm{~A})$.

If we made reference to Hernandez's [6] and Pilloz's (7) works we can think that we have a solid solution enriched in cobalt, result that we'll verify in an ulterior study.

\section{CONCLUSION}

The aim of this study wasn't the research of optimal conditions for the treatments, but the demonstration of the YAG's surface treatment's feasibility. Numerous points must be cleared.

Concerning solid phasis treatments, the rigorous measurments of interaction's efficiency will be implemented owing to microcalorimetric technic. After we'll quantify possible performances. 
Concerning liquid phasis treatments, it appears that a winning exists if we use a YAG laser. For the same treated depth, the usefull power is 2 times lower.

Now we must characterize very strongly the microstructure in order to see if significant differences exist; We think of hypereutectic aluminum alloy for which Marchione [4] has shown an evolution due to the cooling speed.

Concerning the cladding, absoption phenomena versus powder's granulometry and spatial repartition of the energy must be take into account.

That's what we propose to do later.

\section{BIBLIOGRAPHY}

[1] BADAWI (K.F.) ; ANDRZEJEWSKI (H.) ; GREVEY (D.) ; GUYOT (J.L.)

Etude de l'invariant de Lagrange-Smith d'un faisceau laser YAG de 1,2kw;

Soumis au Journal de Physique III.

[2] FOUQUET (F.) ; RENAUD (L.) et al.

Traitement thermique superficiel d'une fonte grise perlitique par faisceau laser.

Mémoires et études scientifiques. Revue de Métallurgie, Janvier 1991, pp.23-31

[3] KIRAT (P.) ; PELLETIER (J.M.) ; VANNES (A.B.) , CRIQUI (B.)

Laser surface treatments in the automotive industry : handening of a precoated grey cast iron.

Proceeding of $24^{\text {th }}$ ISATA. International Symposium on automitive technology and automation

Florence, 20-24 Mai 1991, pp. 119-126

[4] MARCHIONE (M.)

Etude comparative de traitement de surface entre un laser YAG et un laser $\mathrm{CO}_{2}$

Rapport interne T 58 - EPFL - Lausanne Décembre 1990

[5] GAFFET (E.) ; PELLETIER (J.M.) ; BONNET-JOBEZ (S.)

Laser surface alloying of Ni film on al based alloy. Acta Metallurgica, $1989 n^{\circ} 37$,

pp. 3205-3215

[6] HERNANDEZ (J.)

Etude de structures bimétalliques réalisées à l'aide de faisceaux de haute énergie (PLASMA, PTA, LASER). Determination et modélisation des contraintes

résiduelles.

Thése de doctorat INSA, 1986, pp. 235

[7] PILLOZ (M.)

Revêtements laser multicouches multimatériaux : maitrise des traitements et des contraintes résiduelles.

Thèse de doctorat: INSA de Lyon, 1990, pp. 232

[8] GREVEY (D.F.) ; BADAWI (K.F.)

Spatial characterization of YAG power laser beam. Proceeding of the 4th

European congress on optics; The Hague, pp. 11-15, Mars 1991 


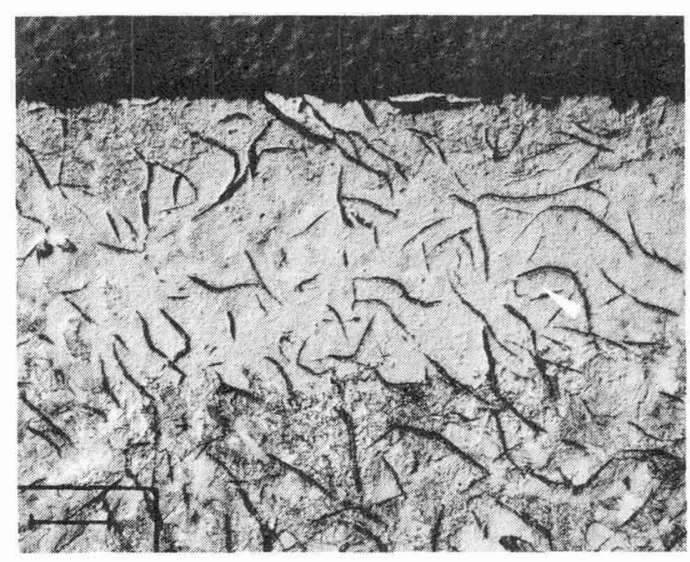

Fig. 1 : cross-section of a YAG laser treated grey cast iron;

$P=600 W \div \Phi=2 \mathrm{~mm} ; \mathrm{V}=55 \mathrm{~cm} / \mathrm{mn} ; \mathrm{G}=125$.

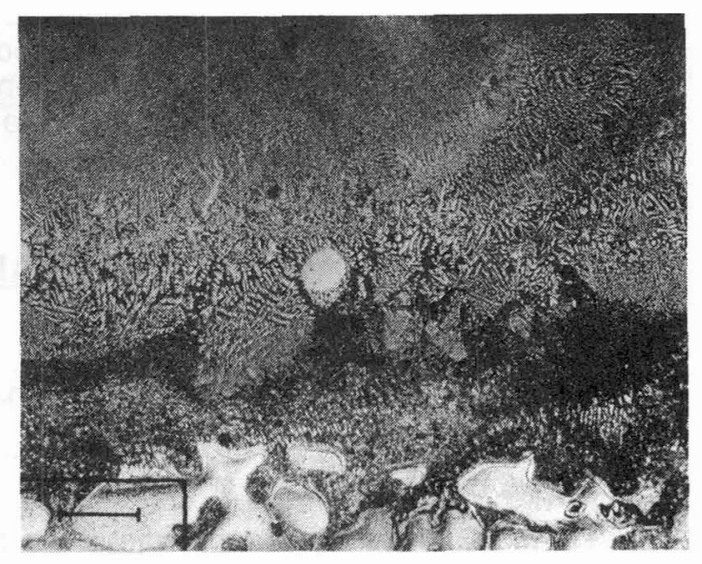

Fig. 2 : micrograph of the laser surface alloy obtained by melting of a $\mathrm{Ni}$ predeposited layer on an Al-Si substrate;

$P=760 \mathrm{~W} ; \Phi=1 \mathrm{~mm} ; \mathrm{V}=1 \mathrm{~m} / \mathrm{mn} ; \mathrm{G}=125$.

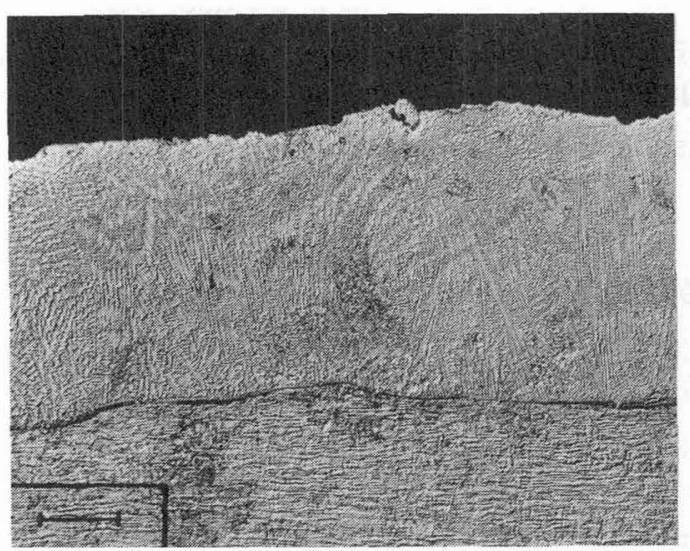

Fig. 3 : micrograph of a Co-base coating on a stainless steel;

$\mathrm{P}=1100 \mathrm{~W} ; \Phi=1 \mathrm{~mm} ; \mathrm{v}=90 \mathrm{~cm} / \mathrm{mn} ; \mathrm{G}=125$.

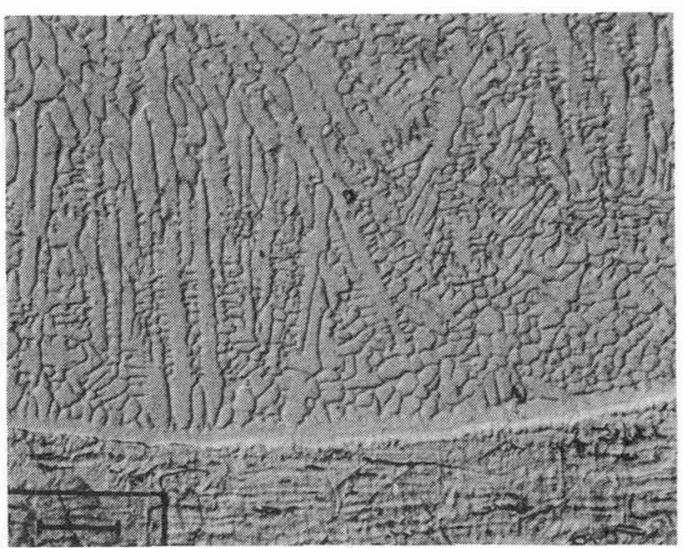

Fig. 4 : optical micrograph exhibiting the plane front growth between the substrate and the coating;

$P=1100 \mathrm{~W} ; \Phi=1 \mathrm{~mm} ; \mathrm{v}=90 \mathrm{~cm} / \mathrm{mn} ; \mathrm{G}=500$. 